\title{
Effectiveness of Giving Loss of Rosella Tea on Decreasing Blood Pressure in Elderly Patients of Hypertension in Working Areas Puskesmas Sengkol Village Sengkol 2 District Pujut Regency of Central Lombok
}

\author{
Edy Surya Pratama ${ }^{1)}$, Dita Retno Pratiwi ${ }^{2)}$, Lalu Jupriadi ${ }^{3)}$ \\ Email: edysurya31@gmail.com

\begin{abstract}
${ }^{1}$ Program Studi S1 Keperawatan, Universitas Qamarul Huda Badaruddin, NTB, Indonesia
${ }^{2}$ Program Studi D III Kebidanan, Universitas Qamarul Huda Badaruddin, NTB, Indonesia

${ }^{3}$ Program Studi DIII Farmasi, Universitas Qamarul Huda Badaruddin, NTB, Indonesia
\end{abstract}

\begin{abstract}
ABSTRAK
Hipertensi adalah gangguan sistem peredaran darah yang menyebabkan kenaikan tekanan darah diatas nilai normal, yaitu melebihi $140 / 80 \mathrm{mmHg}$. Data menjelaskan dari jumlah kunjungan lansia Penderita hipertensi di Puskesmas Sengkol setiap tahun mengalami peningkatan. Dan dari hasil wawancara menyebutkan bahwa angka kejadian penyakit hipertensi paling tinggi dibandingkan dengan Puskesmas yang berada di Kabupaten lombok Tengah. Sehingga penulis tertarik untuk melakukan penelitian. Penelitian ini bertujuan untuk mengetahui efektifitas pemberian seduhan teh rosella terhadap penurunan tekanan darah pada lansia penderita hipertensi. Jenis penelitian ini adalah pre-eksperimen. Populasi dalam penelitian ini sebanyak 45 orang dengan jumlah sampel sebanyak 14 responden, penelitian ini menggunakan analisis bivariat menggunakan uji paired t-test. Rata-rata TD lansia sebelum diberikan seduhan teh rosella yaitu $152.86 / 93,57 \mathrm{mmHg}$, Sedangkan setelah diberikan seduhan teh rosella menjadi $147,14 / 87,86 \mathrm{mmHg}$. Dalam penelitian ini ada pengaruh secara bermakna terhadap penurunan tekanan darah sistole dengan p-value $0,000<\square(0,05)$, dan untuk tekanan darah diastole dengan p-value $0,000<\square(0,05)$. Saran dalam penelitian ini sebagai masukan bagi puskesmas dalam meningkatkan pelayanan dan perawatan pada pasien yang mengalami hipertensi.
\end{abstract}

Kata Kunci: Hipertensi, The Rosella, Tekanan Darah

\begin{abstract}
Hypertension is a circulatory system disorder that causes a rise in blood pressure above the normal value, which exceeds $140 / 80 \mathrm{mmHg}$. The data explained from the number of elderly visits Hypertension sufferers at the Sengkol Health Center each year experienced an increase. And from the results of interviews, the highest incidence of hypertension is compared to the health Central Lombok District. So the author is interested in doing research. This study aims to determine the effectiveness of the administration of rosella tea to reduce blood pressure in elderly people with hypertension. This type of research is pre-experiment. The population in this study were 45 people with a total sample of 14 respondents, this study used bivariate analysis using paired t-test. The average elderly blood pressure before being given rosella tea is $152.86 / 93.57 \mathrm{mmHg}$, while after being given rosella tea to 147.14 / $87.86 \mathrm{mmHg}$. In this study there was a significant effect on the decrease in cystole blood pressure with p-value $0,000<$ $(0,05)$, and for diastolic blood pressure with p-value $0,000<(0,05)$. Suggestions in this study as input for health central in improving services and care for patients who have hypertension.
\end{abstract}

Keywords: Hypertension, Rosella Tea, Blood Pressure

\section{A. LATAR BELAKANG}

Kejadian hipertensi di Indonesia terus menerus mengalami peningkatan sebanyak satu milyar orang di dunia atau satu dari empat orang dewasa dan lansia menderita penyakit hipertensi bahkan pada tahun 2025 diperkirakan jumlah penderita hipertensi akan meningkat menjadi 1,6 milyar [1]. 
Berdasarkan penjelasan diatas laporan sepuluh besar penyakit di Puskesmas Sengkol Desa Sengkol 2 menujukan bahwa penyakit hipertensi berada pada urutan ke 5 dengan angka kejadian 764 .

Data jumlah kunjungan penderita hipertensi di puskesmas sengkol tahun 2014 dengan jumlah kunjungan penderita hipertensi $6,89 \%$ orang, tahun 2015 dengan jumlah kunjungan penderita hipertensi 7,42\% orang, dan pada tahun 2016 dengan jumlah kunjungan penderita $7,64 \%$ orang.

Berdasarkan penjelasan diatas yang didapatkan dari jumlah kunjungan lansia Penderita hipertensi di Puskesmas Sengkol dapat diketahui bahwa jumlah lansia penderita pada setiap tahun mengalami peningkatan. Hal ini tentunya mendorong pemerintah daerah untuk melakukan upaya khusus demi meningkatkan kualitas hidup masyarakat terutama lansia penderita hipertensi di wilayah Puskesmas Sengkol. Jumlah lansia penderita hipertensi di Desa Sengkol 2 sebanyak 45 orang. Meningkatnya jumlah lansia penderita hipertensi tentunya akan menimbulkan angka kematian yang sangat tinggi dikarenakan lansia penderita hipertensi dari tahun ke tahun semakin meningkat. Hal ini disebabkan karena kurangnya kesadaran individu akan pentingnya menjaga dan merawat dirigaya hidup, pola makan, dan lain sebagainya adalah salah satu faktor penyebab terjadinya hipertensi pada individu tersebut.

Hipertensi dapat diatasi dengan pemberian obat-obatan herbal. Banyak tanaman obat atau herbal yang berpotensi di manfaatkan sebagai obat antihipertensi. Mekanisme umum tanaman obat dalam mengontrol tekanan darah antara lain, memberikan efek dilatasi pada pembuluh darah dan menghambat angiotensin converting enzym (ACE). Penghambatan sistem renin-angiotensin memungkinkan dapat menurunkan kemampuan ginjal dalam meningkatkan tekanan darah [2].

Rosella (Hibiscussabdariffa) merupakan salah satu tanaman herbal yang bermanfaat mencegah penyakit kanker, melancarkan tekanan darah, dan melancarkan buang air besar. Bagian dari bunga rosella ini yang di gunakan dan bermanfaat yaitu kelopak bunga rosella. Rosella telah digunakan secara luas di banyak negara sebagai minuman dan sumber pengobatan. Beberapa pengobatan herbal menggunakan ekstrak tanaman ini untuk diuretik, gangguan pencernaan, agen antioksidan, dan hiperkolesterolemia [3].

Potensi rosella besar untuk dikembangkan menjadi obat herbal antihipertensi, bunga rosella ini dapat tumbuh disekitar lingkungan masyarakat desa Kamiwangi dengan mudahnya. Penanaman, perawatan, dan pengolahan bunga rosella juga tergolong mudah. Namun hanya sedikit dari masyarakat Desa Sngkol 2 yang mengetahui manfaat dan kegunaan bunga rosella. Pada lain hal, sudah banyak studi yang menunjukkan dan membuktikan kandungan dan manfaat yang terkandung di dalamnya, namun belum banyak studi maupun bukti ilmiah yang mendukung bunga rosella sebagai anti hipertensi [4].

Berdasarkan latar belakang di atas, maka penulis tertarik untuk meneliti lebih jauh tentang "efektifitas pemberian seduhan teh rosella terhadap penurunan tekanan darah pada lansia penderita hipertensi di Wilayah Kerja Puskesmas Sengkol Desa Sengkol 2 Kecamatan Pujut Kabupaten Lombok Tengah tahun 2017'.

\section{B. METODE PENELITIAN}

Desain penelitian yang digunakan oleh peneliti adalah rancangan eksperimen semu (Quasi Eksperiment Design) dengan jenis rancangan pretest-posttest. Dalam rancangan ini dilakukan randomisasi, artinya pemilihan lansia yang akan diberikan eksperimen dilakukan berdasarkan teknik acak atau random. Kemudian dilakukan pretest (01) pada lansia tersebut, dan diikuti intervensi (X) pada lansia yang sudah terpilih. Setelah beberapa waktu dilakukan posttest (02) pada lansia yang sudah diberi intervensi [5]. Sampel adalah sebagian atau wakil populasi yang diteliti. Dinamakan penelitian sampel apabila kita bermaksud untuk menggeneralisasikan hasil penelitian sampel [6]. Sampel dalam penelitian ini adalah penderita hipertensi sebanyak 14 orang. 
Tehnik sampling adalah proses menyeleksi porsi dari populasi [7]. Teknik sampling dalam penelitian ini diperoleh dengan purposive sampling yang akan dikriteriakan sesuai dengan kriteria yang telah di tetapkan oleh peneliti.

\section{Kriteria inklusi}

1. Penderita hipertensi yang tergolong hipertensi grade 1 (140/90-159/99 mmHg) dan grade $2(160 / 100 \mathrm{mmHg})$.

2. Penderita hipertensi yang tidak mendapatkan terapi obat anti hipertensi.

3. Penderita yang tidak memiliki riwayat penyakit DM

4. Penderita hipertensi yang berumur $45-60$ tahun

Kriteria eksklusi

1. Penderita yang merokok

2. Penderita yang tidak kooperatif

\section{HASIL DAN PEMBAHASAN}

1. Penurunan Tekanan Darah pada Penderita Hipertensi

Tabel 1. Nilai Rata-rata Tekanan Darah Penderita Di Desa Sengkol 2 Kecamatan Pujut Kabupaten Lombok Tengah Tahun 2018

\begin{tabular}{|l|l|c|c|c|c|}
\hline Variabel & Intevensi & N & $\begin{array}{c}\text { Mean } \\
(\mathrm{mmHg})\end{array}$ & $\begin{array}{c}\text { SD } \\
(\mathrm{mmHg})\end{array}$ & $\begin{array}{c}\text { p- } \\
\text { value }\end{array}$ \\
\hline TD & Sebelum & 14 & 152.86 & 9.945 & 0,000 \\
Sistole & Setelah & & 147.14 & 6.112 & \\
\hline TD & Sebelum & 14 & 93.57 & 9.288 & 0,000 \\
Diastole & Setelah & 14 & 87.86 & 6.993 & \\
\hline
\end{tabular}

Berdasarkan hasil uji statistik pada tabel diatas, menunjukkan bahwa sebelum diberikan seduhan teh rosella, rata-rata tekanan darah sistole lansia sebesar $152.86 \mathrm{mmHg}$ dan diastolenya $93.57 \mathrm{mmHg}$, kemudian mengalami penurunan menjadi TD sistole $147.14 \mathrm{mmHg}$ dan TD diastole $87.86 \mathrm{mmHg}$. Hal ini menunjukkan bahwa setelah diberikan seduhan teh rosella, tekanan darah baik sistole maupun diastole lebih rendah dibandingkan dengan sebelum diberikan pemberian seduhan teh rosella. Berdasarkan uji t, didapatkan nilai $t$ hitung untuk TD sistole 2.511 dengan p-value sebesar 0,026 dan untuk TD diastole t hitung sebesar 3.309 dengan p-value 0,006 . Nilai $p$ value diperoleh 0,054 lebih kecil $\alpha=0,05$ artinya ada pengaruh yang signifikan pemberian seduhan teh rosella Di Desa Sebngkol 2 Kecamatan Pujut Kabupaten Lombok Tengah.

Rata-rata tekanan darah responden sebelum perlakuan menunjukan nilai rata-rata tekanan darah sistolik sebelum $152.86 \mathrm{mmHg}$ dan tekanan sistolik sesudah $147.14 \mathrm{mmHg}$ Dan tekanan darah Diastolik sebelum perlakuan 93.57 $\mathrm{mmHg}$ dan tekanan Diastolik sesudah perlakuan $87.86 \mathrm{mmHg}$.

Antosianin yang merupakan komponen bioaktif yang terdapat pada bunga rosella mempunyai efek penurunan tekanan darah. Dalam penelitiannya 32 responden dengan hipertensi. Pengukuran tekanan darah dilakukan setelah responden diistirahatkan selama lima menit, kemudian diberi seduhan bunga rosella sebanyak $300 \mathrm{ml}$. Tekanan darah responden selanjutnya diukur pada saat 90 menit setelah pemberian seduhan bunga rosella. Hasilnya mampu menurunkan tekanan darah sistolik dari 139.05 menjadi $123,73 \mathrm{mmHg}$. Sementara tekanan darah diastolik turun dari 90.81 menjadi $79.52 \mathrm{mmHg}[8]$.

Terjadinya penurunan tekanan darah pada responden dikarenakan rajin mengkonsumsi seduhan teh rosella setiap harinya dan responden juga memperhatikan pola makannya misalnya seperti mengurangi konsumsi garam. Responden laki-laki bisa sedikit mengurangi konsumsi rokok, karena rokok dapat memicu peningkatan kecepatan detak jantung serta memicu penyempitan pembuluh darah akibatnya jantung akan bekerja lebih keras untuk dapat memompa darah keseluruhan tubuh sehingga memicu naiknya tekanan darah [9].

\section{Penurunan tekanan darah pada lansia penderita hipertensi}

Nilai rata-rata tekanan darah sistole sebelum pemberian seduhan teh rosella sebesar 152,86 $\mathrm{mmHg}$ dan nilai rata-rata sesudah pemberian seduhan teh rosella sebesar $147.14 \mathrm{mmHg}$. Nilai rata-rata tekanan darah menunjukan terjadi penuruan setelah diberikan seduhan teh rosella, masing-masing penurunan rata-rata tekanan darah diastole sebesar $93.57 \mathrm{mmHg}$ dan sebesar $87.86 \mathrm{mmHg}$. Nilai $p$-value diperoleh 0,006 lebih kecil $\alpha=0,05$ artinya ada pengaruh yang signifikan pemberian seduhan teh rosella Di Desa Sengkol 2 Kecamatan Pujut Kabupaten Lombok Tengah.

Aantosianin yang merupakan komponen bioaktif yang terdapat pada bunga rosella mempunyai efek penurunan tekanan darah. Dalam penelitiannya 32 responden dengan hipertensi. Pengukuran tekanan darah dilakukan setelah responden diistirahatkan selama lima menit, kemudian diberi seduhan bunga rosella 
sebanyak $300 \mathrm{~mL}$. Tekanan darah responden selanjutnya diukur pada saat 90 menit setelah pemberian seduhan bunga rosella. Hasilnya mampu menurunkan tekanan darah sistolik dari 139.05 menjadi $123,73 \mathrm{mmHg}$. Sementara tekanan darah diastolik turun dari 90.81 menjadi $79.52 \mathrm{mmHg}$ [9].

Dari hasil penelitian yang dilakukan, disimpulkan bahwa pemberian seduhan teh Rosella secara bermakna dalam menurunkan tekanan darah pada Lansia hipertensi di Desa Sengkol 2 Kecamatan Pujut Kabupaten Lombok Tengah.

\section{KESIMPULAN}

1. Umur lansia hipertensi yang menjadi responden rata-rata sebesar 60-64 tahun yaitu 11 orang, rata-rata yang berjenis kelamin laki-laki sebesar $35,7 \%$ serta perempuan sebesar $64,3 \%$, rata-rata lansia hipertensi memiliki pekerjaan sebagai petani sebanyak 8 orang dan pedagang 6 orang, serta sebagian besar lansia hipertensi berpendidikan SD sebanyak 7 orang, SMP 2 orang, dan tidak sekolah 5 orang.

2. Nilai rata rata tekanan darah sistolik sebelum pemberian seduhan teh rosella sebesar $152,86 \mathrm{mmHg}$ dan tekanan darah diastolik sebelum perlakuan $93.57 \mathrm{mmHg}$.

3. Tekanan darah sistolik sesudah pemberian seduhan teh rosella sebesar $147.14 \mathrm{mmHg}$ dan tekanan diastolik sesudah perlakuan $87.86 \mathrm{mmHg}$.

4. Ada pengaruh secara bermakna terapi pemberian seduhan teh Rosella terhadap penurunan tekanan darah sistole lansia hipertensi di Desa Sengkol 2 Kecamatan Pujut Kabupaten Lombok Tengah dengan pvalue $0,000<\alpha(0,05)$, dan untuk tekanan darah diastole juga memiliki pengaruh secara bermakna dengan $p$-value $0,000<\alpha(0,05)$.

\section{DAFTAR PUSTAKA}

[1] Armilawaty, dkk (2011).Hipertensi dan Faktor Risikonya Dalam Kajian Epidemiologi, Jakarta.

[2] Mun'im, AE\& Hanani. (2011).Fitoterapi Dasar.Jakarta: Dian Rakyat.

[3] Yuariski, Oki. (2012). "Pengeringan Bunga Rosella (Hibiscus sabdarifa) Menggunakan Pengering Rak Udara Resirkulasi”. Semarang: Universitas Diponegoro.

[4] Andika, AA, dkk. (2014).Pengaruh Pemberian Bungan Rosella Terhadap Perubahan Tekanan Darah Penderita Hipertensi dengan Terapi Captopril Di Desa Kamiwangi Kecamatan Toili Barat Kabupaten Luwuk Banggai. Jurnal Keperawatan vol. 1. /No. 01/Februari 2014.

[5] Notoatmodjo, S. (2010). Metodologi Penelitian Kesehatan.Jakarta: Rineka Cipta

[6] Arikunto. (2010). Metode penelitian. Jakarta: Rineka Cinta.

[7] Nursalam. (2011). Metodologi Penelitian Ilmu Keperawatan. Jakarta: Salemba Medika..

[8] Kusumastuti,IR (2014). Roselle (Hibiscus Sabdariffa Linn) Effects On Lowering Blood Pressure As A Treatment For Hypertension. Medical Journal Of Lampung. Vol. 3 No. 7. 2014.

[9] Novianti.(2015). Hipertensi, Kenali, Cegah Dan Obati.Edisi 1.Yogyakarta: Notebook. 